\title{
Effect of Temperature on Internal Shear Strength Mechanism of Needle-Punched GCL
}

\author{
Yang Yang ${ }^{1, * \mathbb{C}}$, Jianyong $\mathrm{Shi}^{1}$ and Xuede Qian ${ }^{2}$ \\ 1 Key Laboratory of Ministry of Education for Geomechanics and Embankment Engineering, Hohai University, \\ Nanjing 210024, China; soft-ground@hhu.edu.cn \\ 2 Materials Management Division, Michigan Department of Environment, Great Lakes, and Energy (EGLE), \\ 525 West Allegan Street Lansing, Lansing, MI 48933, USA; qianx@michigan.gov \\ * Correspondence: dfygdy@126.com
}

check for updates

Citation: Yang, Y.; Shi, J.; Qian, X. Effect of Temperature on Internal Shear Strength Mechanism of Needle-Punched GCL. Sustainability 2021, 13, 4585. https://doi.org/ $10.3390 /$ su13084585

Academic Editors: Castorina Silva Vieira and Marc A. Rosen

Received: 26 January 2021

Accepted: 17 April 2021

Published: 20 April 2021

Publisher's Note: MDPI stays neutral with regard to jurisdictional claims in published maps and institutional affiliations.

Copyright: (c) 2021 by the authors. Licensee MDPI, Basel, Switzerland. This article is an open access article distributed under the terms and conditions of the Creative Commons Attribution (CC BY) license (https:// creativecommons.org/licenses/by/ $4.0 /)$.

\begin{abstract}
Needle-punched geosynthetic clay liner (NPGCL) has been widely used in landfills. The internal strength of the GCL changes with temperature variation, which affects its application in landfills. A large-scale temperature-controlled direct shear apparatus was developed to study the internal shear strength characteristics of GCL affected by temperature. The internal strength of the GCL was dependent on the bentonite, the fibers, and the interaction between the fibers and the bentonite. The influence of temperature on the internal strength of the GCL was mainly reflected in the displacement at peak strength. However, the peak strength was basically unchanged. The strength of the bentonite and the fibers-reinforced bentonite increased when the temperature increased. The tensile strength of needle-punched fibers decreased with increasing temperature. The peak strength displacement of the fibers-reinforced bentonite decreased with increasing temperature.
\end{abstract}

Keywords: temperature; needle-punched GCL; shear strength; large direct shear test; bentonite; fibers

\section{Introduction}

Geosynthetic clay liner (GCL) has been widely used in landfill liner structures [1,2]. Slip failure along the interface of liner materials is the main form of slope instability [3]. The internal shear strength of GCL and the shear strength characteristics of the interface between GCL and other geosynthetic materials are key factors affecting the safety of GCL-containing liner landfills [4].

GCL internal strength was measured by direct shear, ring shear, and inclined plate [5-20]. The direct shear apparatus with displacement control and stress control has some advantages and disadvantages. Fox and Stark [21] conducted a detailed review of the shear test equipment used to measure the internal and interfacial shear strength of GCL and concluded that direct shear remained the preferred test method. Many scholars conducted direct shear tests on GCL using large-scale apparatus as shown in Table 1. The materials used in the tests include various types of GCL.

GCL is often under high temperature conditions at landfill [29-32]. It was shown that the leachate temperature of copper reached $45^{\circ} \mathrm{C}$ and that of nickel reached $75^{\circ} \mathrm{C}$ [33]. Currently, the strength assessment of GCL is basically conducted at room temperature. Therefore, it is necessary to study the strength characteristics of GCL at temperatures up to about $80^{\circ} \mathrm{C}$. Bareither [22] used direct shear equipment to study the strength characteristics of five different GCLs at different temperatures and hydration conditions, and the peak strength of one of the GCLs decreased by $40 \%$ from $20{ }^{\circ} \mathrm{C}$ to $80{ }^{\circ} \mathrm{C}$. 
Table 1. Published studies of direct and simple shear tests of GCL.

\begin{tabular}{|c|c|c|c|c|c|}
\hline Reference & Sample Size & Normal Stress & Temperature & Condition & Materials \\
\hline Bareither [22] & $\begin{array}{l}150 \mathrm{~mm} \times 150 \mathrm{~mm} \\
300 \mathrm{~mm} \times 300 \mathrm{~mm}\end{array}$ & $\begin{array}{c}100-2000 \mathrm{kPa} \\
100-500 \mathrm{kPa}\end{array}$ & $20-80^{\circ} \mathrm{C}$ & Hydration & $\begin{array}{c}\text { NP-GCL } \\
\text { NHT(W/NW) } \\
\text { NHT(NW/NW) } \\
\text { HT(W/NW) }\end{array}$ \\
\hline Hanson [17] & $305 \mathrm{~mm} \times 406 \mathrm{~mm}$ & $10-300 \mathrm{kPa}$ & $2-40{ }^{\circ} \mathrm{C}$ & $\begin{array}{c}\text { AR } 50 \% 100 \% \\
\text { moisture }\end{array}$ & $\begin{array}{l}\text { GCL-Textured } \\
\text { Geomembrane } \\
\text { NP (NW/NW) } \\
\text { Clay- NP }\end{array}$ \\
\hline Lin [23-25] & Diameter 300 mm & $110-2220 \mathrm{kPa}$ & Room temperature & $\begin{array}{l}\text { Hydration } \\
\text { Dry }\end{array}$ & $\begin{array}{l}\text { (W/NW)GCL- } \\
\text { Textured } \\
\text { Geomembrane }\end{array}$ \\
\hline Fox and Ross [15] & $305 \mathrm{~mm} \times 1067 \mathrm{~mm}$ & $71.9-2071 \mathrm{kPa}$ & Room temperature & Hydration & $\begin{array}{c}\text { NP (NW/NW)GCL } \\
\text { NP (NW/NW)GCL- } \\
\text { Textured } \\
\text { Geomembrane }\end{array}$ \\
\hline Chen [26] & $100 \mathrm{~mm} \times 100 \mathrm{~mm}$ & $19-600 \mathrm{kPa}$ & Room temperature & Hydration & $\begin{array}{c}\text { NP (W/NW)GCL- } \\
\text { Textured } \\
\text { Geomembrane }\end{array}$ \\
\hline Fox and Kim [14] & $406 \mathrm{~mm} \times 1270 \mathrm{~mm}$ & $30.9-384 \mathrm{kPa}$ & Room temperature & Hydration & $\begin{array}{c}\text { NP (W/NW)GCL- } \\
\text { Textured } \\
\text { Geomembrane } \\
\text { NP-GCL }\end{array}$ \\
\hline McCartney [27] & $305 \mathrm{~mm} \times 305 \mathrm{~mm}$ & $50-520 \mathrm{kPa}$ & Room temperature & Hydration & $\begin{array}{c}\text { NHT(W/NW) } \\
\text { HT(W/NW) }\end{array}$ \\
\hline Zelic et al. [28] & $100 \mathrm{~mm} \times 100 \mathrm{~mm}$ & $50-200 \mathrm{kPa}$ & Room temperature & Hydration & $\begin{array}{l}\text { U (W/NW) GCL } \\
\mathrm{U}(\mathrm{W} / \mathrm{W}) \mathrm{GCL}\end{array}$ \\
\hline Olsta and Swan [11] & $\begin{array}{l}150 \mathrm{~mm} \times 150 \mathrm{~mm} \\
300 \mathrm{~mm} \times 300 \mathrm{~mm}\end{array}$ & $350-2800 \mathrm{kPa}$ & Room temperature & Hydration & $\mathrm{NP}(\mathrm{W} / \mathrm{NW}) \mathrm{GCL}$ \\
\hline Triplett and Fox [12] & $406 \mathrm{~mm} \times 1270 \mathrm{~mm}$ & $6.9-486 \mathrm{kPa}$ & Room temperature & Hydration & $\begin{array}{c}\text { NP (W/NW)GCL- } \\
\text { Smooth and } \\
\text { Textured } \\
\text { Geomembrane }\end{array}$ \\
\hline Fox [8] & $406 \mathrm{~mm} \times 1270 \mathrm{~mm}$ & $6.9-279 \mathrm{kPa}$ & Room temperature & Hydration & $\begin{array}{c}\text { GCL U }(W / W) S B \\
(W / W) N P(W / N W) \\
\text { GCL NP }\end{array}$ \\
\hline Gilbert et al. [5] & $290 \mathrm{~mm} \times 430 \mathrm{~mm}$ & $3.5-345 \mathrm{kPa}$ & Room temperature & Hydration & $\begin{array}{l}\text { (W/NW)NP(NW/NW) } \\
\text { GCL-Smooth } \\
\text { and Textured } \\
\text { Geomembrane }\end{array}$ \\
\hline
\end{tabular}

NP: needle-punched U: unreinforced W: woven geotextile NW: nonwoven geotextile HT: heat treated NHT: non heat-treated SB: stitch-bonded.

Currently, research on the shear strength characteristics of GCL was conducted primarily through indoor shear tests to study the product type, hydration, temperature and hydration time, consolidation time, shear rate, shear displacement, the drainage condition of the normal stress, the process of hydration and shear, hydrated solution, and other specific factors of equipment (such as the specimen clamping system) that influence the shear strength characteristics of the GCL alone or with other geosynthetic materials $[4,8,22,28,34,35]$. However, a few studies of the strength formation mechanism of needle-punched GCL have been conducted. The needle-punched GCL consisted of powder bentonite between a woven and a nonwoven geotextile that were needle-punched together to provide internal reinforcement. Therefore, the shear strength of needle-punched GCL is dependent on the strength of the bentonite, the tensile strength of needle-punched fibers, and the interaction between fibers and bentonite. The shear strength and initial tangent modulus of unsaturated soil increases with increasing temperature [36]. Shao [37] studied the effect of temperature on the shear strength of clay soil, and found that the shear strength decreased and increased with increasing temperature, respectively, when the moisture content was greater and less than the critical value. Shibasaki and Yamasaki [38] cooled and heated calcium bentonite, and stick-slip characteristics were observed at high temperature, indicating that the shear characteristics changed with temperature. There was no consensus on the effect of temperature on the soil strength. The mechanical properties of polymer 
materials were reduced with increasing temperature [30,39-42] and increasing temperature may reduce the internal strength of GCL. Studies on fiber-reinforced soil mostly focus on the influence mechanism of the fiber-reinforced soil strength, the influence of freeze-thaw cycles on fiber-reinforced soil, and the influence of the fiber content and other factors [43-47]. Few papers have studied the strength characteristics of fiber-reinforced soil at high temperatures. Increasing temperature may not necessarily lead to the decrease of the shear strength of the GCL.

The shear process of GCL under the maximum normal stress (1000 kPa) and maximum temperature $\left(70{ }^{\circ} \mathrm{C}\right)$ in landfills can be simulated through the large scale temperaturecontrolled direct shear apparatus. According to the structure and manufacture process of the GCL, the strength of GCL was dependent on the three parts. The temperaturecontrolled direct shear tests of the GCL, the bentonite, the fibers and the fibers-reinforced bentonite were conducted to study how the mechanism of temperature affected the shear characteristics of the GCL.

\section{Methods and Materials}

\subsection{A Large Scale Temperature-Controlled Direct Shear Apparatus}

A temperature-controlled direct shear apparatus was modified from the large scale direct shear apparatus that was used to conduct a shear test of geosynthetics at room temperature by Lin [23-25] and Shi [48]. The large scale temperature-controlled direct shear apparatus was developed for the following experimental conditions:

1. Conduct displacement-controlled direct shear experiments on GCLs;

2. Incorporate $300 \mathrm{~mm}$ circular samples according to ASTM D 6243 [49] and Lin [23-25] for normal stress up to $1000 \mathrm{kPa}$;

3. Maintain a constant temperature up to $70{ }^{\circ} \mathrm{C}$ with an accuracy of $\pm 0.5^{\circ} \mathrm{C}$ through water cycling.

The normal stress was applied by hydraulic cylinder which was controlled by the computer. The maximum normal stress could be up to $2.8 \mathrm{MPa}$. The horizontal shear force was powered by an electric machine which could pull the lower shear box forward at a constant displacement rate. The maximum horizontal force was $150 \mathrm{kN}$. The shear displacement, the vertical displacement, and the horizontal force of the sample were measured by the displacement transducers and the tension transducer, and recorded by computer automatically. Free-rolling steel balls were placed between the upper shear box and the lower shear box to ensure the rolling resistance was as small as possible. The calibration test showed that the rolling resistance of the apparatus would not exceed $0.1 \mathrm{kN}$. The inner diameters of the shear boxes were $300 \mathrm{~mm}$.

During the test, water was flowed from the constant-temperature water tank through the circulation pipe to the circulation tank where the sample was placed, as shown in Figure 1. The circulation tank was attached to the lower shear box. The water circulated from the constant-temperature tank to the circulation tank by using water pump, the sample was warmed up gradually, and reached the set temperature finally. Two water level sensors were used to control the water level in the circulation tank around the sample so that the sample was completely immersed. 




Figure 1. Schematic diagram of temperature-controlled direct shear apparatus.

Before testing, the time that the sample took to reach the set temperatures was measured. The temperature of the water was $15.2-18.2^{\circ} \mathrm{C}$. Under the condition of maximum heat transfer between the water and the air, it took $200 \mathrm{~min}$ for the sample to reach the temperature of $70{ }^{\circ} \mathrm{C}$ as shown in Figure 2. The error range was between $-0.5^{\circ} \mathrm{C}$ and $+0.5^{\circ} \mathrm{C}$.



Figure 2. Temperature-time relationships for temperature of $30^{\circ} \mathrm{C}, 50^{\circ} \mathrm{C}$, and $70{ }^{\circ} \mathrm{C}$.

\subsection{Materials}

The needle-punched GCLs were supplied by Shanghai Renzhong Industrial Co., Ltd. Approximately $5 \mathrm{~kg} / \mathrm{m}^{2}$ of sodium bentonite had been sandwiched between a layer of woven geotextile and a layer of non-woven geotextile. The liquid limit and the plastic limit of the bentonite were $236.1 \%$ and $34.9 \%$, respectively. The masses of the non-woven geotextile and the woven geotextile were $139 \mathrm{~g} / \mathrm{m}^{2}$ and $121 \mathrm{~g} / \mathrm{m}^{2}$, respectively. Other physical and mechanical parameters are shown in Table 2. 
Table 2. Geotechnical parameters of the GCL.

\begin{tabular}{ccccccc}
\hline $\begin{array}{c}\text { Geosynthetic } \\
\text { Clay Liner } \\
\text { (GCL) }\end{array}$ & $\begin{array}{c}\text { Thickness } \\
(\mathbf{m m})\end{array}$ & $\begin{array}{c}\text { Peel Strength } \\
(\mathbf{N} / \mathbf{1 0} \mathbf{~ c m})\end{array}$ & $\begin{array}{c}\text { Mass/Area } \\
\left(\mathbf{g} / \mathbf{m}^{2}\right)\end{array}$ & $\begin{array}{c}\text { Swell Index } \\
(\mathbf{m L} / \mathbf{2} \mathbf{~ g})\end{array}$ & $\begin{array}{c}\text { Tensile } \\
\text { Strength } \\
(\mathbf{N} / \mathbf{1 0} \mathbf{~ m m})\end{array}$ & $\begin{array}{c}\text { Vertical } \\
\text { Permeability } \\
(\mathbf{c m} / \mathbf{s})\end{array}$ \\
\cline { 2 - 8 } & 6 & 114 & 5000 & 25 & 1560 & $4.32 \times 10^{-12}$ \\
\hline
\end{tabular}

\subsection{Specimen Preparation and Test Procedure}

1. The GCL sample was cut with a diameter of $300 \mathrm{~mm}$;

2. The non-woven geotextile and woven geotextile of the GCL were bonded to the circular steel plates with special glue called T360 supplied by Dongguan Xianglian Group that provided excellent bonding between polymer and metal. The circular steel plate was perforated so that the water could drain away from the sample. The sample was cured for $24 \mathrm{~h}$ until the strength of the special glue reached the maximal strength.

3. The GCL samples were hydrated following a two-stage hydration procedure $[21,23,50]$. In the first stage of hydration, the GCL sample was put into a water container, and the sample was immersed in water. A pressure of $1 \mathrm{kPa}$ was applied to the GCL sample for $24 \mathrm{~h}$ to reduce the uneven expansion. After the first stage of hydration, the GCL sample was placed into the large temperature-controlled direct shear box. The water level was controlled above the upper surface of GCL, so that the GCL was immersed in the water. The strength of bentonite decreased sharply after the first stage of hydration, and a large amount of bentonite would be extruded from the side of the GCL due to the application of the normal stress. Therefore, according to the Rules of Geotechnical Test (SL237-1999) [51], the fast consolidation method was adopted to perform graded consolidation compression in the second step of hydration. The total time of the second stage of hydration was $24 \mathrm{~h}$.

4. Through the temperature-controlled device, the set temperature circulating water was fed into the direct shear water tank. The shear step could not be conducted until the temperature of the sample reached the set temperature.

5. The shear displacement rate was set as follows: dry state $0.3 \mathrm{~mm} / \mathrm{min}$, hydration state $0.1 \mathrm{~mm} / \mathrm{min}[15,23,49,52,53]$. For the dry samples at room temperature, steps 3 and 4 were ignored. The shear step could not be conducted until the vertical displacement stabilized.

Before the test, repeated tests were conducted, so that the reproducibility of the method could be verified. Figure 3 showed that the maximum error of shear stress was $10 \%$, under the normal stress of $200 \mathrm{kPa}$ at room temperature.

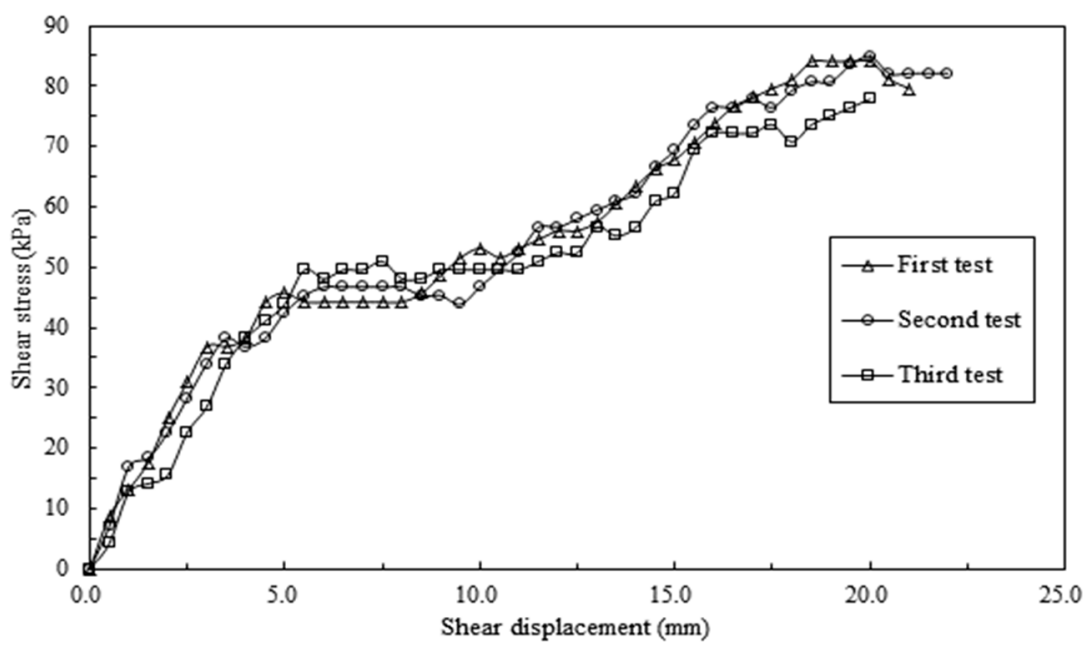

Figure 3. Repeated tests of hydrated GCL at room temperature. 


\section{Results of Tests on the GCL}

Figure 4 shows that the shear stress of the GCL decreased sharply after hydration at the same room temperature, which was caused by the strength of the bentonite after hydration $[4,26]$. The peak shear strength of the GCL decreased between $51.5 \%$ and $64.8 \%$ after hydration.



Figure 4. Shear stress-displacement relationships for dry and hydrated GCLs at room temperature.

Under the same hydration condition, due to the increasing temperature, the peak shear strength of GCL changed slightly, and the peak strength displacement decreased with increasing temperature as shown in Figures 5 and 6 . At room temperature $\left(26.3-27.6{ }^{\circ} \mathrm{C}\right)$, the peak strength displacements of dry GCLs ranged from 10 to $12.5 \mathrm{~mm}$. Under the condition of hydration, the peak strength displacement decreased non-linearly with increasing temperature. As the temperature increased from $30^{\circ} \mathrm{C}$ to $70{ }^{\circ} \mathrm{C}$, the peak strength displacement decreased nearly $15 \mathrm{~mm}$.

During the test, an obvious stress plateau appeared before the shear stress reached the peak strength under dry condition at room temperature and hydration conditions from room temperature to $40^{\circ} \mathrm{C}$. With increasing temperature, the stress plateau gradually decreased when it reached $50{ }^{\circ} \mathrm{C}$, and disappeared completely when the temperature reached $70{ }^{\circ} \mathrm{C}$.

The initial moisture content of the bentonite in the GCL was relatively stable, and remained within the range of $12-15 \%$. After the first step of hydration, the moisture content of the bentonite in the GCL was about $110 \%$. The moisture content of the bentonite in the GCL after shearing is shown in Figure 7, and was mainly affected by normal stress and temperature. At the same temperature, the moisture content of the bentonite decreased as the normal stress increased. Under the same normal stress, the moisture content after the test decreased as the temperature increased. 




(a) Hydrated GCLs at $30^{\circ} \mathrm{C}$



(c) Hydrated GCLs at $50^{\circ} \mathrm{C}$

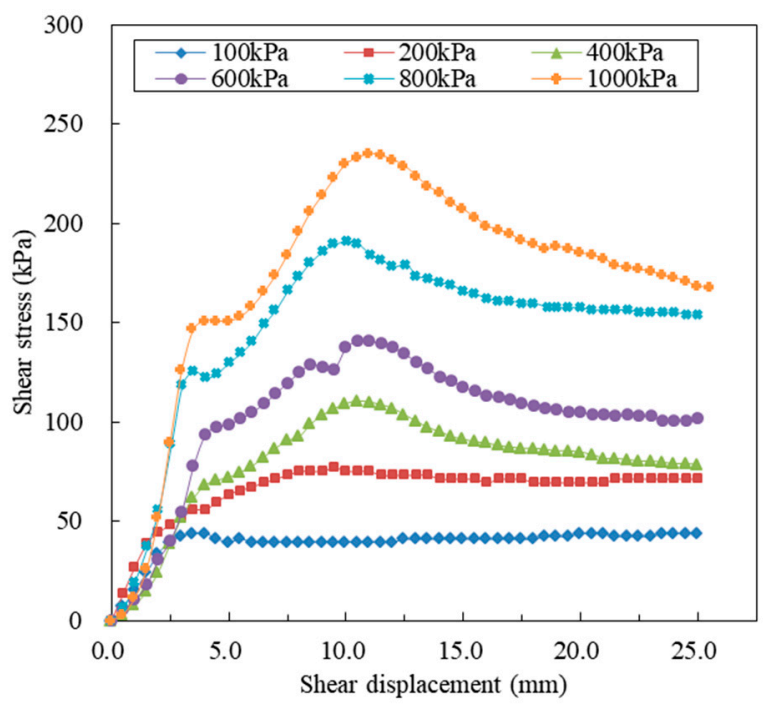

(b) Hydrated GCLs at $40{ }^{\circ} \mathrm{C}$



(d) Hydrated GCLs at $70^{\circ} \mathrm{C}$

Figure 5. Shear stress-displacement relationships for hydrated GCLs. 




Figure 6. Peak strength displacement (PSD) and peak strength (PS) of hydrated GCLs.



Figure 7. Moisture content of bentonite in GCLs after test.

The moisture content of the bentonite in the GCL was taken from three different locations: the center of sample, the edge of sample, and between the center and the edge of the sample. The moisture content at the edge of the sample was the largest, and the least was at the center. The moisture content measured in the test was close to that of other papers, near the fitting curve $\omega=4.94 \times \sigma_{\mathrm{n}}{ }^{-0.282}$ [8].

During the internal shear test of the GCL, the GCL samples were loaded into the shear apparatus after the completion of the first stage of hydration. From the beginning of the second stage of hydration to the end of the shear test, the bentonite in the GCL was extruded from the edge of the sample. After the test, the extruded bentonite was collected and dried. With increasing temperature, the amount of extruded bentonite decreased under the same normal stress as shown in Figure 8. With the increase of normal stress, the amount of bentonite extrusion increased. 




Figure 8. Vertical deformation and mass of extruded bentonite in shear test of the GCL.

After the first stage of hydration, the second stage of hydration was also called the compression stage. The vertical displacements of the specimens in the compression stage and shear stage were collected by linear displacement transducers. The results are shown in Figure 8. The sum of the vertical displacements in the compression stage and shear stage showed the same pattern as the rule of bentonite extrusion, so that the vertical displacements were related to the extrusion of the bentonite. The vertical displacement of the GCL was caused not only by compression of the bentonite, but also by extrusion of the bentonite inside the GCL.

Bareither [22] conducted direct shear tests of five different kinds of GCLs. The temperature increased from $20^{\circ} \mathrm{C}$ to $80^{\circ} \mathrm{C}$, and the internal shear strength of needle-punched GCL was significantly reduced, with a maximum reduction of $40 \%$. In that test, the woven surface and non-woven surface of the GCL were constrained with a pyramid-tooth steel plate. The effectiveness of the pyramid-tooth gripping plates to transfer shear stress into the internal region of a needle-punched GCL was dependent on the peel strength and normal stress. The gripping effectiveness increased as the normal stress increased for a given GCL, or as the GCL peel strength decreased for a given normal stress.

To ensure that the GCL and perforated steel plate were constrained compactly, the woven and non-woven geotextile of GCL was bonded with the circular plate. During the test, none of the fibers were pulled out. The internal fibers were stretched, and the shear failure surface always occurred in the bentonite. It could avoid the damage of fibers pulled out from the woven surface during the shear process.

\section{The Mechanical Behavior of the Components of GCL Internal Strength under the Influence of Temperature}

To study the mechanism of the internal strength characteristics of GCL under the influence of temperature. The influence of the bentonite, the needle-punched fibers, and the interaction between the bentonite and fibers on the internal strength characteristics of the GCL was studied.

\subsection{Shear Strength of the Bentonite}

Temperature-controlled direct shear test of bentonite was conducted with the same apparatus in GCL direct shear test. The moisture content of the bentonite removed from the hydrated GCL sample after the first stage hydration was about $110 \%$. The bentonite was removed from the GCL, and bentonite samples were prepared with the moisture content of $110 \%$. The sample was loaded into the temperature-controlled direct shear box, and 
the rapid consolidation method was adopted to conduct graded compression. The total compression time was $24 \mathrm{~h}$, so that the second stage hydration of GCL was simulated. The shear displacement rates in the dry state and the hydration state were $0.3 \mathrm{~mm} / \mathrm{min}$ and $0.1 \mathrm{~mm} / \mathrm{min}$ respectively.

Comparing the results of the dry bentonite at room temperature $\left(16.1-18.0^{\circ} \mathrm{C}\right)$ with the hydrated bentonite at room temperature $\left(14.9-15.6^{\circ} \mathrm{C}\right)$ in Figure $9 \mathrm{a}$, the peak strength decreased approximately $70.5-80.1 \%$. The main reason that the strength of the GCL decreased sharply after hydration was that the strength of the bentonite decreased after hydration.



(a) Dry and hydrated bentonite at room temperature



(b) Hydrated bentonite at different temperatures

Figure 9. Shear stress-displacement relationships for the bentonite.

Under the condition of hydration, the peak strength of the bentonite increased by $20.5-33 \%$ when the temperature increased from $15{ }^{\circ} \mathrm{C}$ to $70{ }^{\circ} \mathrm{C}$ as shown in Figure 9 . The friction angle increased from $5.4^{\circ}$ to $7.95^{\circ}$. The peak strength of the bentonite was similar to the results obtained from the routine direct shear test at room temperature [24]. With increasing temperature, the moisture content of the bentonite with the same initial moisture content decreased after shearing, while the density of the bentonite increased, as shown 
in Figure 9. The shear strength and the friction angle of the bentonite increased with increasing temperature. The moisture content was the key factor of the shear strength of bentonite [54]. After the shear step, the water around the sample was cooled and released. The moisture content and density of the bentonite was measured from the shear layer. The moisture content of the sample would not change by the evaporation of water in the sample.

The stress plateau appeared in the results of direct shear test on GCL. The peak strength of bentonite accounted for $66.7-93 \%$ of the plateau-stress as shown in Table 3, which indicated that the stress plateau phenomenon in the GCL direct shear test was mainly caused by the shear stress of the bentonite in the GCL reaching the peak strength of the bentonite [24], while other internal forces in the GCL had not fully played their roles.

Table 3. Shear stress $(\mathrm{kPa})$ of the stress plateau before peak strength displacement in the GCL direct shear test.

\begin{tabular}{|c|c|c|c|c|c|c|}
\hline & $100 \mathrm{kPa}$ & $200 \mathrm{kPa}$ & $400 \mathrm{kPa}$ & $600 \mathrm{kPa}$ & $800 \mathrm{kPa}$ & $1000 \mathrm{kPa}$ \\
\hline $30^{\circ} \mathrm{C}$ & $\begin{array}{c}26.0 \\
(5.1-6.1) \\
{[78.5 \%]}\end{array}$ & $\begin{array}{c}42.7 \\
(4.6-6.6) \\
{[66.7 \%]}\end{array}$ & $\begin{array}{c}68.0 \\
(4.5-7.8) \\
{[76.9 \%]}\end{array}$ & $\begin{array}{c}89.1 \\
(4.7-7.7) \\
{[88.1 \%]}\end{array}$ & $\begin{array}{c}108.0 \\
(4.4-7.4) \\
{[93.0 \%]}\end{array}$ & $\begin{array}{c}97.6 \\
(3.9-5.9)\end{array}$ \\
\hline $40^{\circ} \mathrm{C}$ & / & / & $\begin{array}{c}71.4 \\
(3.8-4.4)\end{array}$ & $\begin{array}{c}94 \\
(4.0-4.9)\end{array}$ & $\begin{array}{c}124.0 \\
(3.5-4.1)\end{array}$ & $\begin{array}{c}148.0 \\
(3.7-5.4)\end{array}$ \\
\hline $50^{\circ} \mathrm{C}$ & / & / & $\begin{array}{c}80 \\
(2.7) \\
{[76.6 \%]}\end{array}$ & $\begin{array}{c}100 \\
(3.1-4.0) \\
{[79.5 \%]}\end{array}$ & $\begin{array}{c}139 \\
(3.3-3.5) \\
{[85.5 \%]}\end{array}$ & $\begin{array}{c}131.0 \\
(3.4-4.1)\end{array}$ \\
\hline $70^{\circ} \mathrm{C}$ & / & / & / & / & / & / \\
\hline
\end{tabular}

(Shear displacement of stress plateau/mm); [Proportion of bentonite strength to shear stress of the GCL stress plateau].

\subsection{Tensile Strength of Needle-Punched Fibers}

In order to simulate the effect of needle-punched fibers inside GCL on the internal strength of GCL, the tensile strength of needle-punched fibers under the influence of temperature was studied. The GCL was cut with the diameter of $300 \mathrm{~mm}$ and the bentonite was fully removed from the GCL. The non-woven and woven surfaces of the sample were bonded to the circular steel plate with special glue as same as the GCL sample. To ensure that the woven surface would not be contacted with the non-woven surface, steel balls were placed inside the sample between the woven geotextile and the non-woven geotextile. Normal stress would not be applied in the test. The shear displacement rate was $0.1 \mathrm{~mm} / \mathrm{min}$.

With the increasing temperature, the modulus of the internal fiber decreased, and the peak strength displacement of the fibers increased as shown in Figure 10. At room temperature, the tensile properties of the fibers changed slightly under dry and hydration conditions. The tensile strength of the fibers was mainly affected by temperature. The tensile strength of the needle-punched fibers played a key role at the shear displacement of $10 \mathrm{~mm}$ at room temperature $\left(22^{\circ} \mathrm{C}\right)$ and $20 \mathrm{~mm}$ at $70^{\circ} \mathrm{C}$. Normal stress of the tensile test was zero, and the tensile strength of the fibers only influenced the cohesion of the GCL. Under the same conditions, the sum of the strength of the bentonite and the tensile strength of fibers was less than the internal shear strength of the GCL. Therefore, the interaction between the fibers and bentonite could not be ignored. 


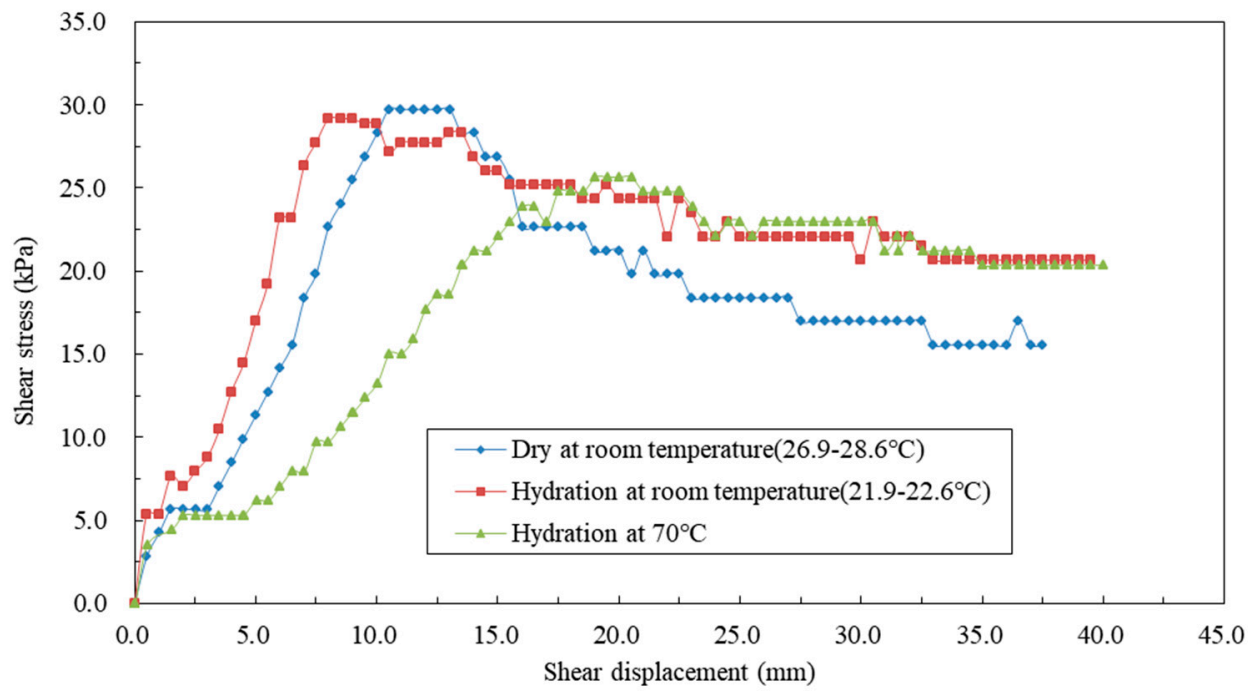

Figure 10. Shear stress-displacement relationships for fibers in the GCL.

\subsection{Shear Strength of Fibers-Reinforced Bentonite}

To study the influence of the interaction between needle-punched fibers and bentonite on the internal strength of GCL, the direct shear test of fibers-reinforced bentonite was conducted. The bentonite and fibers were removed from the GCL, and mixed according to the proportion of the GCL. Other steps in the direct shear test of bentonite were followed.

When an equal proportion of fibers in the GCL were added to the bentonite, the strength of the fibers-reinforced bentonite increased with increasing temperature as shown in Figure 11. However, the peak strength displacement decreased when the temperature increased, which was consistent with the pattern of the GCL. The peak strength displacement of bentonite was constant. Interaction between fibers and bentonite reached the peak strength earlier along with an increasing temperature. The important factor that the peak strength displacement decreased in the GCL direct shear test was that the peak strength displacement of the fibers-reinforced bentonite decreased with increasing temperature. Comparing with the results of the bentonite, the shear strength of the fibers-reinforced bentonite was greater than that of bentonite under the same condition as shown in Figure 12. The friction angle increased $0.47^{\circ}$ under the condition of hydration at $70{ }^{\circ} \mathrm{C}$. The interaction between the fibers and bentonite could not be ignored.



Figure 11. Shear stress-displacement relationships for the fiber-reinforced bentonite. 




Figure 12. Peak strength of three components (bentonite, fibers, fibers-reinforced bentonite).

An obvious stress plateau phenomenon appeared in the shear test of GCL. With increasing temperature, the stress plateau gradually decreased, and disappeared completely when the temperature reached $70^{\circ} \mathrm{C}$. The stress plateau phenomenon was mainly caused by the shear stress of the bentonite reaching the peak strength of the bentonite [22]. The curves of GCL and fibers-reinforced bentonite were compared as shown in Figure 13. Before the shear stress reached the peak strength, there was a period of slow increase of shear stress due to restructuring of fibers and bentonite. The specimen with higher density would be denser at a fixed polymer content, and the grains and polymer additive inside this specimen contacted well, thereby providing a path for the external load to go through, thus resulting in the decreasing of the peak strength displacement [55]. Slow increase of shear stress of fibers-reinforced bentonite was another reason for the stress plateau phenomenon in the result of GCL. The temperature increased to $70{ }^{\circ} \mathrm{C}$, and the stress plateau disappeared with slow increase of shear stress.

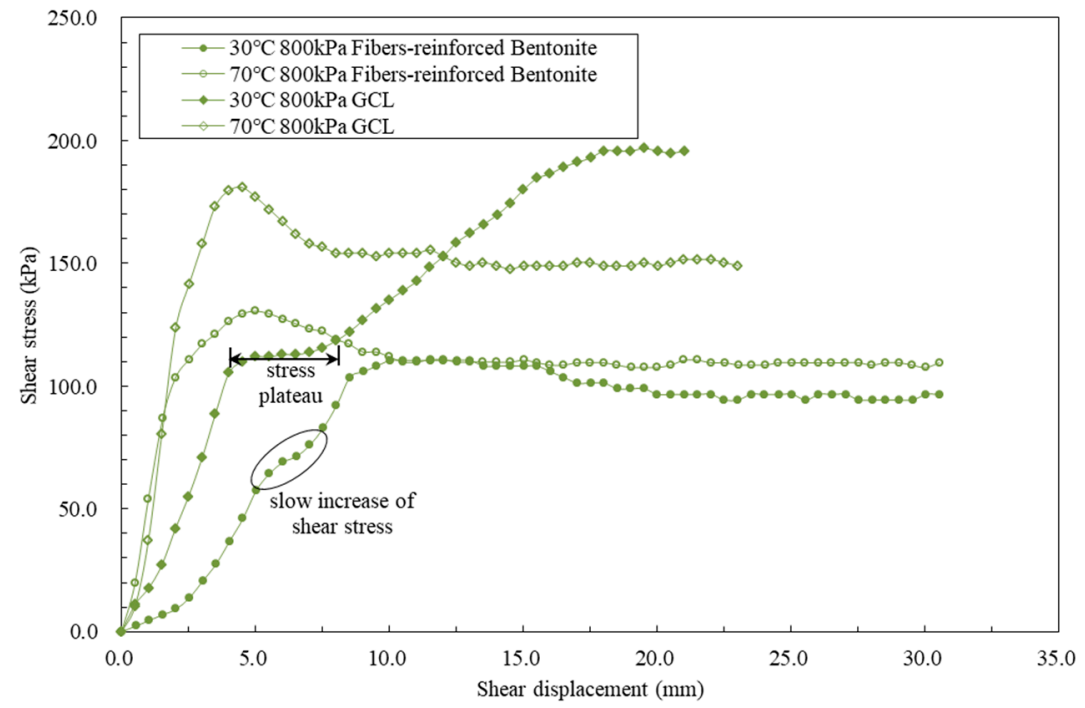

Figure 13. Comparison of shear stress-displacement response of fibers-reinforced bentonite and GCL at $800 \mathrm{kPa}$. 
The results in Table 4 show that the internal strength of the GCL was dependent on three components. Under the influence of temperature, the different shear characteristics of the GCL were caused by different components. Slight variation of the cohesion and shear angle of the GCL did not mean that the components changed slightly. The frictional angle of bentonite increased $2.55^{\circ}$ from room temperature $\left(15^{\circ} \mathrm{C}\right)$ to $70^{\circ} \mathrm{C}$, and the peak strength displacement was constant. The variation trend of the peak strength displacement of the fibers was opposite to that of the fibers-reinforced bentonite. The cohesion and friction angle of fibers-reinforced bentonite increased observably with the increasing temperature. Lin [23-25] conducted a shear test of GCL-geomembrane and found that the peak strength increased along with the normal stress non-linearly, which was attributed to the variation of failure modes of the composite liner.

Table 4. Strength parameters of the GCL and three components.

\begin{tabular}{|c|c|c|c|c|}
\hline Tests & $\begin{array}{c}\text { Temperature } \\
\left({ }^{\circ} \mathrm{C}\right)\end{array}$ & $\begin{array}{c}\mathrm{c}_{\mathrm{p}} \\
(\mathrm{kPa})\end{array}$ & $\begin{array}{l}\varphi_{\mathrm{p}} \\
\left(^{\circ}\right)\end{array}$ & $\begin{array}{c}\delta_{p} \\
(\mathrm{~mm})\end{array}$ \\
\hline \multirow{4}{*}{ GCL } & 30 & 27.23 & 11.80 & $17.3-20.0$ \\
\hline & 40 & 27.03 & 11.53 & $10.0-10.8$ \\
\hline & 50 & 24.14 & 11.24 & $5.8-7.5,10.2-11.1$ \\
\hline & 70 & 26.35 & 11.22 & $4.0-5.6$ \\
\hline $\begin{array}{l}\text { GCL-geomembrane } \\
\text { (Lin 2014) }\end{array}$ & $\begin{array}{c}\text { Room } \\
\text { temperature }\end{array}$ & \multicolumn{2}{|c|}{$\tau_{\mathrm{p}}=\sigma_{\mathrm{n}} \tan 10^{\circ}+6.07 \sigma_{\mathrm{n}}^{0.53}$} & $7.5-14.0$ \\
\hline \multirow{4}{*}{ Bentonite } & 15 & 9.00 & 5.40 & $5.0-6.0,11.0$ \\
\hline & 30 & 9.06 & 6.61 & $4.5-6.5,8.0$ \\
\hline & 50 & 9.20 & 7.21 & $5.0-6.5,13.5$ \\
\hline & 70 & 10.58 & 7.95 & $5.5-6.5,13.0$ \\
\hline \multirow{2}{*}{ Fibers } & 21 & \multirow{2}{*}{\multicolumn{2}{|c|}{$\begin{array}{l}\tau_{\mathrm{p}}=29.16 \mathrm{kPa} \\
\tau_{\mathrm{p}}=25.65 \mathrm{kPa}\end{array}$}} & 10.0 \\
\hline & 70 & & & 20.0 \\
\hline \multirow{2}{*}{$\begin{array}{l}\text { Fibers-reinforced } \\
\text { bentonite }\end{array}$} & 30 & 10.50 & 7.06 & $10.0-12.0$ \\
\hline & 70 & 11.57 & 8.42 & $5.0-6.5,13.5$ \\
\hline
\end{tabular}

\section{Conclusions}

A large scale temperature-controlled direct shear apparatus was developed to study the characteristics of GCL internal shear strength under the influence of temperature. In the test, the internal strength of the GCL was dependent on three parts: the strength of the bentonite, the tensile strength of the needle-punched fibers, and the strength generated by the interaction between the fibers and the bentonite. Shear tests were conducted on the three components to study the mechanism of temperature affected the shear strength of the GCL.

1. Internal shear strength of GCL decreased sharply after hydration, mainly caused by the strength of bentonite decreasing. The phenomenon of the stress plateau gradually disappeared as the temperature increased. When the temperature increased, the internal peak strength of the GCL changed slightly, and the peak strength displacement gradually decreased. The stress plateau phenomenon in the GCL was mainly due to the shear stress of the bentonite closed to its peak strength, and the slow increase of interaction between fibers and bentonite.

2. The shear strength of the bentonite increased with increasing temperature. The tensile strength of the fibers was greatly affected by the temperature. The tensile strength of the fibers only influenced the cohesion of the GCL.

3. The interaction between fibers and the bentonite was not negligible. The shear strength of the fibers-reinforced bentonite increased with increasing temperature, and the peak displacement decreased. Therefore, the interaction between the fibers and bentonite was an important factor leading to the decrease of the peak displacement in the GCL with increasing temperature. 
4. Increasing temperature may not necessarily lead to a decrease in the shear strength of the GCL, which is related to many factors, such as the constraint mode of the sample and the type of the sample. Further studies are needed.

Author Contributions: The idea for this work comes from Y.Y. Design of experiments and evaluation of results was performed by Y.Y. and J.S. Presentation of the results and the structure of the manuscript were discussed with J.S. and X.Q. Y.Y. wrote the draft and included corrections suggested by the coauthors. All authors have read and agreed to the published version of the manuscript.

Funding: The key fund of the China Natural Science Foundation (41530637) provided the financial support.

Institutional Review Board Statement: Not applicable.

Informed Consent Statement: Written informed consent has been obtained from the participants to publish this paper.

Data Availability Statement: The data is available on request to the corresponding author.

Acknowledgments: The authors express their appreciation to AJE Group for checking and revising the language of this paper, and appreciate the financial support provided by the key fund of the China Natural Science Foundation (41530637).

Conflicts of Interest: The authors declare no conflict of interest.

\section{References}

1. Fox, P.J.; De Battista, D.J.; Mast, D.G. Hydraulic performance of geosynthetic clay liners under gravel cover soils. Geotext. Geomembr. 2000, 18, 179-201. [CrossRef]

2. Stark, T.; Arellano, D.; Evans, W.; Wilson, V.; Gonda, J. Unreinforced Geosynthetic Clay Liner Case History. Geosynth. Int. 1998, 5, 521-544. [CrossRef]

3. Qian, X.D.; Koerner, R.M.; Gray, D.H. Geotechnical Aspects of Landfill Design and Construction; Prentice Hall Inc.: Upper Saddle River, NJ, USA, 2002.

4. Qian, X.D.; Shi, J.Y.; Liu, X.D. Design and Construction of Modern Sanitary Landfills; Chinese Architecture Industry Press: Beijing, China, 2011. (In Chinese)

5. Gilbert, R.B.; Fernandez, F.; Horsfield, D.W. Shear Strength of Reinforced Geosynthetic Clay Liner. J. Geotech. Eng. 1996, 122, 259-266. [CrossRef]

6. Siebken, J.R.; Swan, R.H.; Yuan, Z. Short-term and creep shear characteristics of a needle punched thermally locked geosynthetic clay liner. In Testing and Acceptance Criteria for Geosynthetic Clay Liners; ASTM International: West Conshohocken, PA, USA, 1997.

7. Trauger, R.J.; Swan, R.H.; Yuan, Z. Long-term shear strength behavior of a needle punched geosynthetic clay liner. In Testing and Acceptance Criteria for Geosynthetic Clay Liners; ASTM: West Conshohocken, PA, USA, 1997.

8. Fox, P.J.; Rowland, M.G.; Scheithe, J.R. Internal Shear Strength of Three Geosynthetic Clay Liners. J. Geotech. Geoenviron. Eng. 1998, 124, 933-944. [CrossRef]

9. Suits, L.D.; Sheahan, T.; Fox, P.; Nye, C.; Morrison, T.; Hunter, J.; Olsta, J. Large Dynamic Direct Shear Machine for Geosynthetic Clay Liners. Geotech. Test. J. 2006, 29, 392-400. [CrossRef]

10. Koerner, R.M.; Soong, T.Y.; Koerner, G.R.; Gontar, A. Creep testing and data extrapolation of reinforced GCLs. Geotext. Geomembr. 2001, 19, 413-425. [CrossRef]

11. Olsta, J.T.; Swan, R.H. Internal shear strength of a geosynthetic clay liner at high normal loads. In Proceedings of the Tailings and Mine Waste, Fort Collins, CO, USA, 18-19 January 2001.

12. Triplett, E.J.; Fox, P.J. Shear Strength of HDPE Geomembrane/Geosynthetic Clay Liner Interfaces. J. Geotech. Geoenviron. Eng. 2001, 127, 543-552. [CrossRef]

13. Zanzinger, H.; Alexiew, N. Long-term internal shear testing on clay geosynthetic barriers. In Proceedings of the International Symposium on Clay Geosynthetic Barriers, Nuremberg, Germany, 16-17 April 2002.

14. Fox, P.J.; Kim, R.H. Effect of Progressive Failure on Measured Shear Strength of Geomembrane/GCL Interface. J. Geotech. Geoenviron. Eng. 2008, 134, 459-469. [CrossRef]

15. Fox, P.J.; Ross, J.D. Relationship between NP GCL Internal and HDPE GMX/NP GCL Interface Shear Strengths. J. Geotech. Geoenviron. Eng. 2011, 137, 743-753. [CrossRef]

16. Zanzinger, H.; Saathoff, F. Long-term internal shear strength of a reinforced GCL based on shear creep rupture tests. Geotext. Geomembr. 2012, 33, 43-50. [CrossRef]

17. Hanson, J.; Chrysovergis, T.; Yesiller, N.; Manheim, D. Temperature and moisture effects on GCL and textured geomembrane interface shear strength. Geosynth. Int. 2015, 22, 110-124. [CrossRef] 
18. Thielmann, S.S.; Fox, P.J.; Athanassopoulos, C. Shear Strength of GMX/GCL Composite Liner under High Normal Stress. J. Geotech. Geoenviron. Eng. 2016, 142, 04016005. [CrossRef]

19. Zanzinger, H. Contribution to the Long-Term Shear Strength of a Needle Punched GCL. Int. J. Geosynth. Ground Eng. 2016, 2, 1-7. [CrossRef]

20. Ghazizadeh, A.S.; Bareither, C.A. Failure mechanisms of geosynthetic clay liner and textured geomembrane composite systems. Geotext. Geomembr. 2021, 49, 789-803. [CrossRef]

21. Fox, P.; Stark, T. State-of-the-art report: GCL shear strength and its measurement-Ten-year update. Geosynth. Int. 2015, $22,3-47$. [CrossRef]

22. Bareither, C.A.; Soleimanian, M.; Zadeh, S.G. Direct shear testing of GCLs at elevated temperature and in a non-standard solution. Geosynth. Int. 2018, 25, 350-368. [CrossRef]

23. Lin, H.; Shi, J.; Qian, X.; Zhang, L. An improved simple shear apparatus for GCL internal and interface stress-displacement measurements. Environ. Earth Sci. 2013, 71, 3761-3771. [CrossRef]

24. Lin, H. Simple Shear Strength Characteristics of Needle-Punched GCL and Its Application in Landfill Slope Stability Analysis. Ph.D. Thesis, Hohai University, Nanjing, China, 2014. (In Chinese).

25. Lin, H.; Zhang, L.; Xiong, Y. Research on shear strength of needle-punched GCL by simple-shear of composite liner. Eng. Geol. 2018, 244, 86-95. [CrossRef]

26. Chen, Y.M.; Lin, W.A.; Zhan, T.L. Investigation of mechanisms of bentonite extrusion from GCL and related ef-fects on the shear strength of GCL/GM interfaces. Geotext. Geomembr. 2010, 28, 63-71. [CrossRef]

27. McCartney, J.S.; Zornberg, J.G.; Swan, R.H. Analysis of a Large Database of GCL-Geomembrane Interface Shear Strength Results. J. Geotech. Geoenviron. Eng. 2009, 135, 209-223. [CrossRef]

28. Zelić, B.K.; Znidarčić, D.; Kovačić, D. Shear strength testing on a GCL. In Proceedings of the 7th International Conference on Geo-Synthetics, Nice, France, 22-27 September 2002.

29. Yeşiller, N.; Hanson, J.L.; Liu, W.-L. Heat Generation in Municipal Solid Waste Landfills. J. Geotech. Geoenviron. Eng. 2005, 131, 1330-1344. [CrossRef]

30. Stark, T.D.; Jafari, N.H.; Rowe, R.K. Service life of a landfill liner system subjected to elevated temperatures. J. Hazard. Toxic Radioact. Waste 2014, 18, 16-26.

31. Hanson, J.L.; Yeşiller, N.; Oettle, N.K. Spatial and Temporal Temperature Distributions in Municipal Solid Waste Landfills. J. Environ. Eng. 2010, 136, 804-814. [CrossRef]

32. Koerner, G.; Koerner, R. Long-term temperature monitoring of geomembranes at dry and wet landfills. Geotext. Geomembr. 2006, 24, 72-77. [CrossRef]

33. Thiel, R.; Smith, M.E. State of the practice review of heap leach pad design issues. Geotext. Geomembr. 2004, 22, 555-568. [CrossRef]

34. Hewitt, R.; Soydemir, C.; Stulgis, R.; Coombs, M. Effect of normal stress during hydration and shear on the shear strength of GCL/texture geomembrane interfaces. In Testing and Acceptance Criteria for Geosynthetics Clay Liners; ASTM: West Conshohocken, PA, USA, 1997.

35. Zornberg, J.G.; McCartney, J.S.; Swan, R.H. Analysis of a Large Database of GCL Internal Shear Strength Results. J. Geotech. Geoenviron. Eng. 2005, 131, 367-380. [CrossRef]

36. Xie, Y.; Chen, Z.H.; Li, G. Research of thermal effects on shear strength and deformation characteristics of un-saturated bentonite soils. Yantu Gongcheng Xuebao 2015, 27, 1082-1085. (In Chinese)

37. Shao, Y.X.; Shi, B.; Gao, L.; Gu, K.; Zhao, L.Z. Laboratory Study on Influence of Temperature on Shear Strength of Unsaturated Clayey Soil. Geol. J. China Univ. 2009, 19, 139-144. (In Chinese)

38. Shibasaki, T.; Yamasaki, T. Experimental investigation on temperature effect on residual strength characteristics of soils. J. Jpn. Landslide Soc. 2010, 47, 255-264. [CrossRef]

39. Andrawes, K.Z.; McGown, A.; Kabir, H. Uniaxial strength testing of woven and nonwoven geotextiles. Geotext. Geomembr. 1984, 1, 41-56. [CrossRef]

40. Ariyama, T.; Mori, Y.; Kaneko, K. Tensile properties and stress relaxation of polypropylene at elevated tempera-tures. Polym. Eng. Sci. 1997, 37, 81-90. [CrossRef]

41. Kongkitkul, W.; Tabsombut, W.; Jaturapitakkul, C.; Tatsuoka, F. Effects of temperature on the rupture strength and elastic stiffness of geogrids. Geosynth. Int. 2012, 19, 106-123. [CrossRef]

42. Karademir, J.D.; Frost, J.D. Micro-scale tensile properties of single geotextile polypropylene filaments at elevat-ed temperatures. Geotext. Geomembr. 2014, 42, 201-213. [CrossRef]

43. Gray, D.H.; Ohashi, H. Mechanics of Fiber Reinforcement in Sand. J. Geotech. Eng. 1983, 109, 335-353. [CrossRef]

44. Tang, C.; Shi, B.; Gao, W.; Chen, F.; Cai, Y. Strength and mechanical behavior of short polypropylene fiber reinforced and cement stabilized clayey soil. Geotext. Geomembr. 2007, 25, 194-202. [CrossRef]

45. Hamidi, A.; Hooresfand, M. Effect of fiber reinforcement on triaxial shear behavior of cement treated sand. Geotext. Geomembr.s 2013, 36, 1-9. [CrossRef]

46. Roustaei, M.; Eslami, A.; Ghazavi, M. Effects of freeze-thaw cycles on a fiber reinforced fine grained soil in rela-tion to geotechnical parameters. Cold Regions Sci. Technol. 2015, 120, 127-137. [CrossRef]

47. Wei, H.; Zhao, T.; Meng, Q.; Wang, X.; He, J. Experimental Evaluation of the Shear Behavior of Fiber-Reinforced Calcareous Sands. Int. J. Géoméch. 2018, 18, 04018175. [CrossRef] 
48. Shi, J.; Shu, S.; Qian, X.; Wang, Y. Shear strength of landfill liner interface in the case of varying normal stress. Geotext. Geomembr. 2020, 48, 713-723. [CrossRef]

49. ASTM D 6243-09 Standard Test Method for Determining the Internal and Interface Shear Resistance of Geosyn-Thetic Clay Liner by the Direct Shear Method; American Society for Testing and Materials: West Conshohocken, PA, USA, 2009.

50. Fox, P.J.; Stark, T.D. State-of-the-art report: GCL shear strength and its measurement. Geosynth. Int. 2004, 11, 141-175. [CrossRef]

51. Geotechnical Test Procedure (SL-237-1999); China Water and Power Press: Beijing, China, 1999. (In Chinese)

52. Eid, H.; Stark, T. Shear Behavior of an Unreinforced Geosynthetic Clay Liner. Geosynth. Int. 1997, 4, 645-659. [CrossRef]

53. Eid, H.T. Shear strength of geosynthetic composite systems for design of landfill liner and cover slopes. Geotext. Geomembr. 2011, 29, 335-344. [CrossRef]

54. Chen, H.; Lv, H.B. Strength and volume change of buffer material under high temperature and pressure. Chin. J. Rock Mech. Eng. 2018, 37, 1962-1979. (In Chinese)

55. Li, W.; Kwok, C.Y.; Senetakis, K. Effects of inclusion of granulated rubber tyres on the mechanical behaviour of a compressive sand. Can. Geotech. J. 2020, 57, 763-769. [CrossRef] 